ISSN 1392-3196 / e-ISSN 2335-8947

Zemdirbyste-Agriculture, vol. 104, No. 2 (2017), p. 115-122

DOI 10.13080/z-a.2017.104.015

\title{
Empirical models of transformations of humic acids and humin in Umbric Albeluvisol Abruptic as influenced by liming
}

\author{
Andrey LITVINOVICH ${ }^{1}$, Olga PAVLOVA ${ }^{1}$, Anton LAVRISHCHEV ${ }^{2}$, Vladimir BURE ${ }^{1,3}$, \\ Elmira SALJNIKOV ${ }^{4}$
}

${ }^{1}$ Agrophysical Research Institute

Grazhdanskii 14, 195220 St. Petersburg, Russia

${ }^{2}$ St. Petersburg State Agrarian University

Peterburgsoye 2, 196601 St. Petersburg, Russia

${ }^{3}$ St. Petersburg State University

Universitetskaya Emb. 7/9, 199034 St. Petersburg, Russia

${ }^{4}$ Soil Science Institute

Teodora Drajzera 7, 11000 Belgrade, Serbia

E-mail: soils.saljnikov@gmail.com

\begin{abstract}
The research studied the changes in total carbon (C) content - carbon of humic acids (HA), and non-hydrolysable residue - humin (NR) in Umbric Albeluvisol Abruptic (umABap) under application of a wide range of doses (0.12.5 hydrolytic acidity (Hy), meq per $100 \mathrm{~g}$ of soil) of lime in the controlled conditions of a pot experiment. The trend of decreasing of total humus content in the soil was revealed only under application of the highest dose $(2.5 \mathrm{Hy})$ of lime. A gradual decline in the proportion of humin and increase in the proportion of humic acids correspondingly to the doses of lime was observed. The correlation coefficient between humin and $\Sigma$ HA was $r=-0.49$. Moderately negative correlation between the content of humin and humic acid 1 (HA1) "free" and bound with sesquioxides was found: $r=-0.37$; between humin and humic acid 2 (HA2), bound to calcium: $r=-0.75$. HA1 and HA2 fractions were not significantly correlated. The increase in the humus content of humic acid 3 (HA3) that is tightly bound with clay minerals and stable forms of sesquioxides was found only starting from the dose of lime corresponding to $0.9 \mathrm{Hy}$. At a dose of lime, equal to $2.5 \mathrm{Hy}$ its content in humus exceeded the content of HA2. The hypothesis of the research suggesting that the source of replenishment of the portion of humic acids might be the organic substances of humin was proved. The empirical models of transformation of humic acid and humin as influenced by increasing doses of lime and in the process of its dissolution were developed. Optical densities of humic acids were presented.
\end{abstract}

Key words: fractionation, humic acid fractions, humin, hydrolytic acidity, liming.

\section{Introduction}

Chemical analyses of soil organic matter based on the principles of fractionation into groups and fractions, mainly humic and fulvic acids are widely presented in the literature (Aleksandrova, 1980; Clapp et al., 2005; Kögel-Knabner et al., 2006; Schmidt et al., 2011; LopezSangil, Rovira, 2013).

Studies of the effect of liming on the individual groups and fractions of soil organic matter remain among the priority tasks for theory and application of liming. Despite the complexity of this analysis, recently, there has been an increase in the number of similar works (Takahashi et al., 2006; Litvinovich, Pavlova, 2007; 2010; Zavyalova, 2010; Liaudanskienè et al., 2011; Jokubauskaite et al., 2015). In the process of liming, simultaneous changes of soil acidity and content of mobile forms of elements that primarily bound humic substances in soil (Al, Fe and $\mathrm{Ca}$ ) take place (Takahashi et al., 2006). These changes affect the amount of associated humic acids. Calcium applied to soil with lime more actively interacts with humic acid compared to fulvic acid, forming more resistant compounds (Litvinovich et al., 2000; Bakina, Drichko, 2011). For better understanding of transformations

Please use the following format when citing the article:

Litvinovich A., Pavlova O., Lavrishchev A., Bure V., Saljnikov E. 2017. Empirical models of transformations of humic acids and humin in Umbric Albeluvisol Abruptic as influenced by liming. Zemdirbyste-Agriculture, 104 (2): 115-122 DOI 10.13080/z-a.2017.104.015 
and changes in soil organic matter fractions it is often necessary to have not only the experimental data but also application of appropriate models that can process large number of measurements and provide most informative outcomes.

In our study, we used the modified Plotnikova and Orlova (1984) method attempting to address this shortcoming by including a sequential extraction of all the fractions and groups from one soil sample.

The aim of this research was to develop the mathematical models that adequately describe the changes in the composition of humic substances in acidic sod-podzolic soil (Unified State Register of soil resources in Russia, 2014), which corresponds to the Umbric Albeluvisol Abruptic (WRB, 2014) under application of increasing doses of lime, to study changes in humus transformation during the process of lime dissolution and to analyse the relationship of indicators of individual groups of humic substances in the process of transformation in soil humus under liming.

\section{Materials and methods}

The objective of the research was to study the transformations of humic acid (HA) and humin under the increasing doses of lime and during the process of its dissolution in Umbric Albeluvisol Abruptic (umABap). The pot experiment was conducted in 2006-2011 in a greenhouse of the Agrophysical Research Institute, St. Petersburg, Russia. The soil samples for the experiment were collected from A1 horizon at a depth of $0-15 \mathrm{~cm}$ from natural meadow, located $30 \mathrm{~km}$ from St. Petersburg. Physical and chemical characteristics of the soil were: $\mathrm{pH}$ in $\mathrm{KCl}-4.1$, hydrolytic acidity (Hy) $-5.4 \mathrm{mmol}(\mathrm{eq})$ $100 \mathrm{~g}^{-1}$ of soil, carbon (C) content in humus $-1.75 \%$, content of particles smaller than $0.01 \mathrm{~mm}-18.6 \%$.

Before filling the $5-\mathrm{kg}$ plastic pots the soil was sieved through a $2 \mathrm{~cm}$ mesh sieve, after removing large roots, stones and clods. Then the soil was thoroughly mixed and placed in pots containing the ameliorant and mineral fertilizer. Liming was performed once before establishment of the experiment. The conversion chalk - a by-product of nitrate processing of phosphate raw materials in the production of nitrogen fertilizers was used as an ameliorant. Ameliorant has finely dispersed particle size distribution. It passes entirely through a sieve with a mesh diameter of $<0.25 \mathrm{~mm}$. The chemical composition of lime: $\mathrm{CaCO}_{3}-90 \%, \mathrm{P}-0.9 \%$ and $\mathrm{N}-1.5 \%$.

Fertilizer as NPK (16:16:16) was applied each year before planting at a rate of $0.2 \mathrm{~g}$ per $1 \mathrm{~kg}$ of soil during refilling the pots. The experimental design is shown in Table 1. In the experiment, rape, vetch, wheat, rape and rape were successively grown. Rape and vetch were harvested at flowering stage. Wheat was brought to full maturity. Every treatment of the experiment was set in four replications. Soil moisture throughout the experiment was kept at $60 \%$ of full field moisture capacity.

The study of changes in the total carbon content and the transformation of humic acid and humin with increasing doses of lime were performed after harvesting the vetch, i.e. two years after setting up the experiment. Soil samples were collected annually after harvesting from each experiment pot.

Preparation of the soil to determine total carbon was as follows: after removing visible roots the soil samples were ground, sieved through $0.25 \mathrm{~mm}$ mesh. After removing fine roots using an electrified ebony stick, the soil was weighed and poured with $\mathrm{K}_{2} \mathrm{Cr}_{2} \mathrm{O}_{7}$ (potassium dichromate) solution prepared with concentrated sulphuric acid at 1:1 ratio. Then the samples were boiled for $5 \mathrm{~min}$ on a sand-stove, cooled and titrated by $0.1 \mathrm{~N}$ Mohr salt solution. Transformation of the humic acids and humin within the humus and during the process of dissolution of lime was studied in the treatment with lime dose corresponding to $2.5 \mathrm{Hy}$ meq per $100 \mathrm{~g}$ of soil. The investigations were carried out for five years.

The studies of transformations of humic acids were performed by Plotnikova and Orlova (1984) method. For this analysis the soil was sampled from each pot, sieved through $1 \mathrm{~mm}$ mesh. Combined HA1 + FA1 (fluvic acid) fraction was extracted by $0.1 \mathrm{~N} \mathrm{NaOH}$ (sodium hydroxide). For determination of HA2 + FA2 the de-calcination pre-treatment of initial soil followed by extraction by $0.1 \mathrm{~N} \mathrm{NaOH}$ was performed. The HA3 + FA3 fraction was extracted by $0.02 \mathrm{~N} \mathrm{NaOH}$ at 6 -hour heating in a water bath, after extraction of HA2 + FA2 fraction. From the total solutions, the humic acids were precipitated by addition of $1 \mathrm{~N} \mathrm{H}_{2} \mathrm{SO}_{4}$ solution, followed by heating to $70-80^{\circ} \mathrm{C}$. The flakes of humic acids formed after heating in total solutions were transferred to a filter, followed by dissolving in hot $0.1 \mathrm{~N} \mathrm{NaOH}$ solution. The solution volume was adjusted to $100 \mathrm{ml}$. An aliquot of $40 \mathrm{ml}$ was evaporated on a water bath. Determination of carbon of humic acids was carried out by Tyurin (1937) method.

Each fraction of humic acids was examined for optical density $\left(\mathrm{E}_{\mathrm{c}} \mathrm{mg} \mathrm{ml}^{-1}\right)$ by passing the solution through the photo-electro-colorimeter with $1 \mathrm{~cm}$ cuvette thickness at $430 \mathrm{~nm}$ wavelength, blue filter. In this paper, the transformation of fulvic acids was not considered. The obtained data were statistically processed (Bure, Parilina, 2013).

\section{Results and discussion}

According to modern concepts, the influence of liming on the content of organic matter is composed of two opposing processes. On the one hand, liming of acid soils improves the conditions for microorganisms, accelerates the decomposition of high-molecular components of soil humus and contributes to the decrease of humus content in the soil. On the other hand, liming, greatly improves the development of crops, increases the amount of crop residues in soil, including roots. The net result of these two processes depending on the specific conditions (soil and biological characteristics of crops) can be both decrease and increase in the content of soil humus.

In our studies in the treatments with increasing doses of lime (from 0.1 to 1.6 of $\mathrm{Hy}$ ) the content of humus ranged from $1.5 \%$ to $1.7 \% \mathrm{C}$ (Table 1 ). A clear pattern of changes of humus content with increasing dose of ameliorant was not established. Probably, the increased amount of crop residues due to the liming, balanced the accelerated decomposition of organic matter what may be one of the possible reasons that content of humus was not significantly different between the control and limed treatments. Using $2.5 \mathrm{Hy}$ lime dose showed visible tendency of humus content decrease up to $1.4 \%$ C. The effect of increasing doses of lime on the content of different fraction of humic acids and humin is shown in Table 1. 
Table 1. Effect of increasing doses of ameliorant on transformation of humic acids (HA) and non-hydrolysable residue in Umbric Albeluvisol Abruptic sandy loam soil

\begin{tabular}{|c|c|c|c|c|c|c|}
\hline \multirow{2}{*}{ Treatment } & \multirow{2}{*}{$\begin{array}{c}\text { Total C } \\
\%\end{array}$} & \multirow[b]{2}{*}{ HA1 } & \multirow[b]{2}{*}{ HA2 } & \multirow[b]{2}{*}{ HA3 } & \multirow[b]{2}{*}{$\Sigma \mathrm{HA}$} & \multirow{2}{*}{ Humin } \\
\hline & & & & & & \\
\hline Initial soil & 1.70 & $\frac{0.29}{17.2}$ & $\frac{0.06}{3.5}$ & $\frac{0.11}{6.4}$ & $\frac{0.46}{27.1}$ & $\frac{0.74}{43.6}$ \\
\hline Control (NPK) & 1.70 & $\frac{0.22}{13.1}$ & $\frac{0.09}{5.4}$ & $\frac{0.20}{11.6}$ & $\frac{0.51}{30.1}$ & $\frac{0.62}{36.3}$ \\
\hline Control + lime (0.1 Hy) & 1.61 & $\frac{0.27}{17.0}$ & $\frac{0.12}{7.3}$ & $\frac{0.15}{9.1}$ & $\frac{0.53}{33.4}$ & $\frac{0.40}{24.6}$ \\
\hline Control + lime (0.3 Hy) & 1.52 & $\frac{0.28}{18.4}$ & $\frac{0.14}{9.2}$ & $\frac{0.10}{7.2}$ & $\frac{0.52}{34.8}$ & $\frac{0.35}{23.2}$ \\
\hline Control + lime (0.6 Hy) & 1.50 & $\frac{0.27}{18.0}$ & $\frac{0.17}{11.3}$ & $\frac{0.15}{10.0}$ & $\frac{0.59}{39.3}$ & $\frac{0.38}{25.1}$ \\
\hline Control + lime (0.7 Hy) & 1.61 & $\frac{0.28}{17.6}$ & $\frac{0.20}{12.5}$ & $\frac{0.11}{6.9}$ & $\frac{0.59}{37.0}$ & $\frac{0.42}{26.5}$ \\
\hline Control + lime (0.9 Hy) & 1.61 & $\frac{0.24}{15.1}$ & $\frac{0.22}{13.6}$ & $\frac{0.17}{10.8}$ & $\frac{0.63}{39.5}$ & $\frac{0.38}{23.9}$ \\
\hline Control + lime (1.6 Hy) & 1.70 & $\frac{0.29}{16.9}$ & $\frac{0.26}{15.1}$ & $\frac{0.20}{12.0}$ & $\frac{0.75}{44.0}$ & $\frac{0.32}{18.6}$ \\
\hline Control + lime (2.5 Hy) & 1.40 & $\frac{0.22}{15.7}$ & $\frac{0.16}{11.4}$ & $\frac{0.20}{14.0}$ & $\frac{0.58}{41.1}$ & $\frac{0.29}{20.7}$ \\
\hline $\mathrm{LSD}_{05}$ & 0.31 & 3.51 & 3.45 & 3.14 & 4.04 & 4.55 \\
\hline
\end{tabular}

Note. Above the line is \% to soil; below the line is \% to total C; LSD is given for content to total C; Hy - hydrolytic acidity.

The study showed that increasing dose of lime led to increased hydrolysability of humus. In the treatment without liming, the content of humin was $0.62 \% \mathrm{C}$, while liming with 2.5 Hy dose it decreased by more than twice $(0.29 \%$ C). Many researchers studied composition of insoluble residue of soil organic matter. Tyurin (1937) showed that together with humin compounds formed from aging humic acid, there are some compounds that are in the state of transition into humic acid.

Based on the generalized data of Russian researchers, Kononova (1963) concluded that humin of soil humus is an acid similar to humic acids extracted from soil after de-calcification. She explained insolubility of these humic acids by the strong bonds with the mineral soil particles. According to Alexandrova (1980), in podzolic soils the non-humified substance accounts for $62 \%$ of carbon of non-hydrolysable residue. Thus, the amount of poorly decomposed plant residues in the composition of non-hydrolysable residue can be quite significant. Cherkinsky (1992) emphasizes the young age of humic substances of humin. He suggests that organic substances of humin can be one of the sources for formation of humic acids, because they include poorly decomposed plant residues.

Together with a gradual decline in the share of humin in humus under the influence of increasing doses of lime, the increase of humic acids share was observed. The correlation coefficient was $r=-0.49$. Thus, the source of replenishment of humic acids under liming can be organic substances of humin, because of the two factors: firstly, due to additional humification of half decomposed plant residues included in the humin; secondly, due to the loosening of bonds between humin substances and soil mineral particles because of cultivation. This results in increase of humic acids content that are chemically extracted from soil. Liaudanskiene et al. (2011) found that sustainable soil use significantly increases the content of humic acids bound to soil clay minerals. The results of Pridvorev et al. (2006) study on Voronic Chernozem Pachic soil showed that the humic substances present in humin are early pre-humic compounds preceding formation of humic and fluvic acids, which actively interact with soil mineral part. Along with them, there are present the transformation products of humic acids. Under agricultural use of Voronic Chernozem Pachic the bonds of newly formed humic substances with mineral soil break down faster. Therefore, under intensive land use of Chernozem soils the humic substances of humin are subject to greater losses than fluvic acids. Thus, nonhydrolysable residue is not a passive stable fraction, but heterogeneous mixture of old and new organic substances.

Umbric Albeluvisol Abruptic is characterized with domination of humic acid 1 (HA-1) that is "free" or bound to non-silicate (flexible) sesquioxides, soluble in $0.1 \mathrm{~N} \mathrm{NaOH}$. Numerous researches established that during liming the main process is regrouping in the composition of the fractions, where most optically dense part HA1 replenishes HA2 (humic acids bound to calcium) (Jokubauskaite et al., 2016).

In our study, the least amount of HA1 was recorded in the treatment without liming. In most liming treatments, the amount of HA1 was significantly higher than in the control. In the treatment with $2.5 \mathrm{Hy}$ lime the amount of HA1 decreased up to the level of the control treatment, what is explained by decrease of total carbon content due to over-liming.

Thus, liming of Umbric Albeluvisol Abruptic with increasing doses under controlled pot experiment leads to the replenishment of HA1 pool. While not denying the possibility of the regrouping of humic acids within the humus as influenced by calcium of lime, we note that during the correlation analysis of HA1 and HA2 the following results were obtained:

$r($ "HA1", "HA2") $=0.4429$.

The value $t-$ statistics $(\mathrm{n}=8): t$ ( $r$ ("HA2", "HA1")) = 1.21.

The critical point of the Student distribution, corresponding to the significance level of 0.05 (two-tailed test), with 6 degrees of freedom, $t(0.05 ; 6)=2.4469$. 
The obtained results imply that $t$ ( $r$ ("HA2", "HA1") $\mid<t(0.05 ; 6)$, which means non-significant negative correlation at the $5 \%$ level between indicators "HA1" and "HA2". The critical point of the Student distribution, corresponding to the significance level of 0.1 (two-tailed test), with 6 degrees of freedom, $t(0.1$; $6)=1.943$. It corresponds to the equation $\mid t$ ( $r$ ("HA2", "HA1") $\mid<t(0.1 ; 6)$ showing non-significant negative correlation at the $10 \%$ significance level.

Thus, the Pearson correlation coefficient value allows us to make a conclusion about the absence of a significant correlation between the indicators "HA1" and HA2" in our experiment.

This conclusion is also confirmed by the results of optical density of humic acids. Increasing share of HA1 under liming is accompanied by increase of values of optical density $\left(\mathrm{E}_{\mathrm{c}} \mathrm{mg} \mathrm{m}^{-1}\right)$ HA1 (Table 2). Chemical value of the optical density is determined as an intensity of the staining of alkali solution of organic matter per unit of carbon. The darker the solution the more carbon is in it. At equal concentration of carbon in the solution the optical density depends on the depth of humification (aromatization) of its humic substances.

Table 2. Changes in optical density $\left(\mathrm{E}_{\mathrm{c}} \mathrm{mg} \mathrm{ml}^{-1}\right)$ of humic acids (HA) under application of increasing doses of ameliorant

\begin{tabular}{cccc}
\hline Treatment & HA1 & HA2 & HA3 \\
\hline Control + lime (0.1 Hy) & 5.0 & 8.0 & 4.0 \\
Control + lime (0.3 Hy) & 7.6 & 7.7 & 3.5 \\
Control + lime (0.6 Hy) & 7.8 & 8.5 & 3.0 \\
Control + lime (0.7 Hy) & 7.0 & 9.0 & 3.0 \\
Control + lime (0.9 Hy) & 6.0 & 10.0 & 3.5 \\
Control + lime (1.6 Hy) & 5.0 & 12.6 & 5.1 \\
Control + lime (2.5 Hy) & 4.3 & 12.9 & 6.1 \\
\hline LSD $_{05}$ & 1.5 & 1.4 & 1.3 \\
\hline
\end{tabular}

Hy - hydrolytic acidity

In the case of regrouping HA1 and HA2 in the humus, their optical density should decrease, because optical density of HA2 bound to calcium is always higher than optical density of HA1, but less than the optical density of the new HA2. In our case, the optical density of HA1 in the soil before setting up the experiment was $4 \mathrm{E}_{\mathrm{c}} \mathrm{mg} \mathrm{ml}^{-1}$, and increased in the treatments with liming at $0.1-1.6 \mathrm{Hy}$ up to $5.0-7.8 \mathrm{E}_{\mathrm{c}} \mathrm{mg} \mathrm{m}^{-1}$. Simultaneously, optical density of HA2 increased from 5 in the initial soil to 7-12 $\mathrm{E}_{\mathrm{c}} \mathrm{mg} \mathrm{ml}^{-1}$ in the treatments with liming. Therefore, along with an increase in the proportion of HA1 and HA2 in the humus composition an increase of their optical density occurs, i.e. the replenishment of the humic acids occurs at the expense of more aromatized humic acids.

Statistical analysis showed that the correlation coefficient between the humin and HA 1 was characterized by medium negative value: $r=-0.37$. Thus, the source of replenishment HA1 can be organic substances of humin. Increase of HA2 content under the influence of increasing doses of ameliorant was observed up to the dose of $1.6 \mathrm{Hy}$ lime. In general, because of the nature of the chemical structure the humic acids may form only a small amount of calcium humate. In our studies, the maximum level of HA2 accumulation in the humus with increasing dose of ameliorant did not exceed $15.1 \%$ (Litvinovich, Pavlova, 2007).
Using the lime corresponding to a 2.5 Hy showed a decrease in the amount of HA2. Perhaps this is due to increased mineralization of this fraction $\mathrm{C}$ when liming. Correlation analysis of the relationship between HA2 and humin (non-hydrolysable residue, NR) was as follows:

$r$ ("HA2", "NR") $=-0.7484$.

The value $t-$ statistics $(\mathrm{n}=9): t(r$ ("HA2", "NR")) $=-2.985$, where NR is non-hydrolysable residue. The critical point of the Student distribution, corresponding to the significance level of 0.05 (two-tailed test), with 7 degrees of freedom, $t(0.05 ; 7)=2.364$.

These results imply that $\mid t(r$ ("HA2", "NR") $\mid>t$ $(0.05 ; 7)$. Consequently, there is a statistically significant linear relationship at 5\% level of significance between indicators HA2 and NR. This correlation is negative, that is, the trend of increase of one indicator corresponds to the trend of decreasing of another indicator. It is necessary to note that starting from the lime rate corresponding to 0.9 $\mathrm{Hy}$, an increase of HA3 content in humus was recorded. Compared to the treatment with 0.7 Hy lime dose its content increased by $0.06 \%$. At the same time the total carbon content remained unchanged. Increasing the dose of lime to $1.6 \mathrm{Hy}$ contributed to a further increase in the proportion of HA3 in the humus composition. Reduction of total carbon content at over-liming (dose of lime 2.5 Hy) did not lead to a decrease in the proportion of this fraction in the humus composition.

Apparently, in the presence of a sufficient amount of calcium the binding of humic acids by mineral part of soil is stronger than under low $\mathrm{pH}$ and base unsaturation. This is reflected in the increase in the content of HA3 in humus. This phenomenon is quite natural, although the nature of it is currently difficult to explain; therefore, we are limited to a simple statement of facts. This can be confirmed by a fractional-group composition of humus of Rendzina Leptosols Eutric, which are formed in a similar climatic zone. Their distinctive feature is high content of HA3, whose share may reach up to $50 \%$ of total carbon. The share of HA2 in humus of these soils is non-significant (Orlova, 1981).

In the treatment with a 0.9 Hy lime an increase of HA3 content in the humus is accompanied by a decrease in the proportion of HA1. We can assume that in this case the replenishment of HA1 fraction from humin is slower than their fixing on the surface of clay particles. In the treatment with a high dose of lime (1.6 Hy) these processes are balanced. Indirect evidence in favour of this hypothesis can be the data of the optical density. Starting from the 0.9 Hy lime rate optical density of HA1 gradually decreases and optical density of HA3 gradually increases. Obviously, HA3 is replenished by most optically dense HA1.

Further we discuss the mathematical models of the effect of lime doses (variable $\mathrm{x}$ ) on HA1, HA2, HA3 and humin (variables $\mathrm{y}_{1}, \mathrm{y}_{2}, \mathrm{y}_{3}$ and $\mathrm{y}_{4}$ ) as a function of $\mathrm{x}$.

Fraction HA1. Fourth level polynomial was chosen for the modelling of the dynamics of changes in HA1. Applying linear regression, the following model No. 1 was developed:

$$
\mathrm{y}_{1}=0.22445+0.4399 \mathrm{x}-0.9309 \mathrm{x}^{2}+0.64657 \mathrm{x}^{3}
$$
$-0.13796 x^{4}$ model 1,

where $\mathrm{x}$ is a lime rate.

Model No. 1 is statistically significant at 7\% $(F=7.309)$ at critical values $F(0.93 ; 4.3)=7.0685$ with high approximation $\left(R^{2}=0.907\right)$ (Fig. 1). 


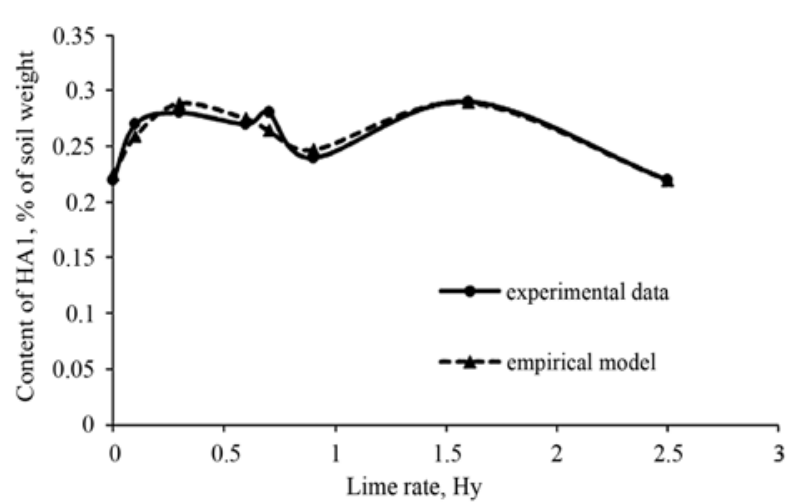

Figure 1. Changes in the content of humic acid HA1 under increasing rate of lime

Fraction $\boldsymbol{H A 2}$ is associated with calcium and is the most agronomically valuable fraction of humus. In natural Umbric Albeluvisol Abruptic this fraction is not present or present in negligible amounts. But under liming the amount of HA2 fraction increased proportionally to the rates of lime and to the amount of exchangeable $\mathrm{Ca}$ and $\mathrm{Mg}$ (Litvinovich, Pavlova, 2010; Bakina et al., 2014). For the development of the model of the dynamics of changes in HA2 under the increasing lime rates a polynomial of third level was chosen. Using the linear regression, the following model No. 2 was developed:

$$
\mathrm{y}_{2}=0.096+0.141 \mathrm{x}+0.0154 \mathrm{x}^{2}-0.0246 \mathrm{x}^{3}
$$

model 2

where $\mathrm{x}$ is the lime rate.

The developed model No. 2 is statistically significant at $5 \%(F=95.8)$ at critical values $F(0.95 ; 3.4)$ $=6.591$ with high approximation $\left(R^{2}=0.986\right)$ (Fig. 2$)$.

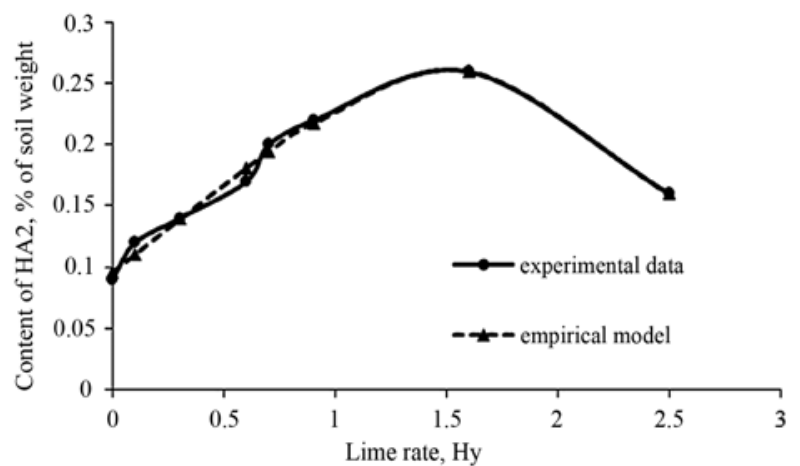

Figure 2. Changes in the content of humic acid HA2 under increasing rate of lime

Fraction $\boldsymbol{H A 3}$ is strongly associated with persistent forms of sesquioxides and clay minerals. In the original scheme of Tyurin, this fraction was proposed to be extracted by alternate treatment of soil with acid and alkali. The scheme Ponomareva and Plotnikova (1968) used single treatment with $0.02 \mathrm{~N} \mathrm{NaOH}$ solution after 6-hour boiling in water bath.

The fourth level polynomial was applied for the mathematical modelling of the changes in HA3. Using the linear regression, analyses model No. 3 was developed: $+0.12415 \mathrm{x}^{4}$ $\mathrm{y}_{3}=0.19785-0.56986 \mathrm{x}+1.082 \mathrm{x}^{2}-0.65185 \mathrm{x}^{3}$ where $x$ is the lime rate.
The model No. 3 is statistically significant at $13 \%(F=4.604)$ at critical values $F(0.87 ; 4.3)=4.309$ with high approximation $\left(R^{2}=0.856\right)$ (Fig. 3$)$. The model is statistically significant and reflects the main tendency of changes in HA3.

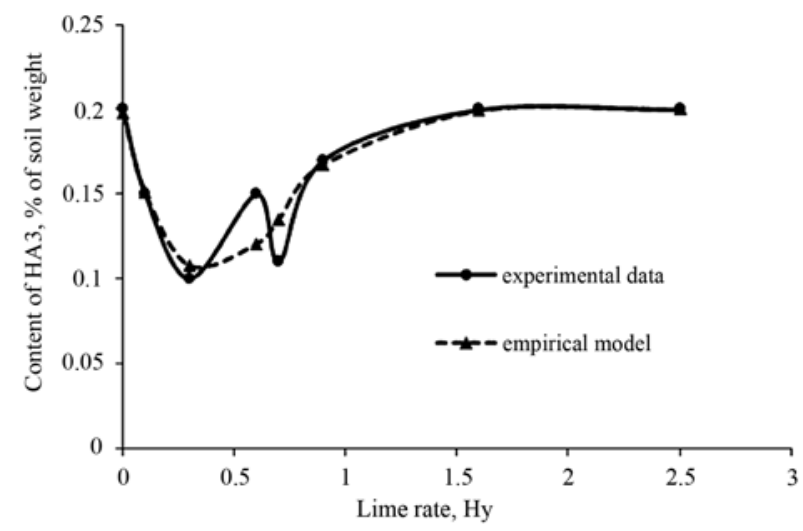

Figure 3. Changes in the content of humic acid HA3 fraction under increasing rate of lime

Humin (NR). For mathematical modelling of the changes in humin content similar model and regression analysis were used: $\begin{array}{r}\mathrm{y}_{4} \\ +0.3673 \mathrm{x}^{4} \\ \hline\end{array}$

$$
\mathrm{y}_{4}=0.5796-1.4459 \mathrm{x}+2.74475 \mathrm{x}^{2}-1.80325 \mathrm{x}^{3}
$$

where $\mathrm{x}$ is the lime rate.

The model No. 4 is statistically significant at $12 \%(F=4.764)$ at critical values $F(0.88 ; 4.3)=4.606$ with high approximation $\left(R^{2}=0.864\right)$ (Fig. 4$)$. The model correctly reflects the main tendency of the changes in the content of humin.

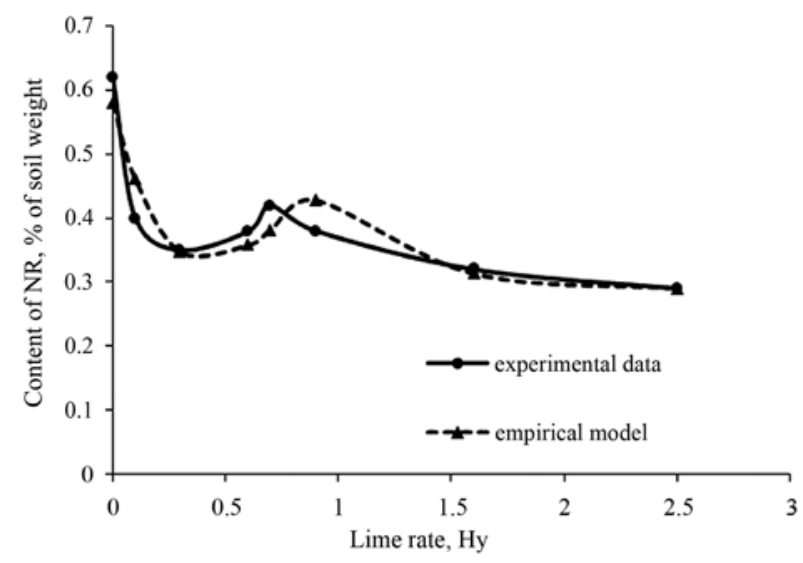

Figure 4. Changes in the content of humin (NR) fraction under increasing rate of lime

Changes in the composition of humus during the dissolution of lime are shown in Table 3. More detailed description of the humus composition in this experiment is given in the paper (Litvinovich, Pavlova, 2014).

As an empirical model of the dynamics of transformation of the fractions of humic acids HA1, HA2, HA3 and humin during the dissolution of the ameliorant a third level polynomial and linear regression was applied: 
Table 3. Transformation of humic acids (HA) and humin (non-hydrolysable residue) in Umbric Albeluvisol Abruptic sandy loam soil during the dissolution of the applied ameliorant

\begin{tabular}{|c|c|c|c|c|c|c|}
\hline \multirow{2}{*}{ Treatment } & \multirow{2}{*}{$\begin{array}{c}\text { Total C } \\
\%\end{array}$} & \multicolumn{4}{|c|}{ Fractions of HA } & \multirow{2}{*}{ Humin } \\
\hline & & 1 & 2 & 3 & $\Sigma$ & \\
\hline $\begin{array}{c}\text { Control (NPK) + lime at } 2.5 \mathrm{Hy} \\
2006 \text { year }\end{array}$ & 1.5 & $\frac{0.27}{18.0}$ & $\frac{0.11}{7.3}$ & $\frac{0.16}{10.7}$ & $\frac{0.54}{36.0}$ & $\frac{0.40}{26.5}$ \\
\hline $\begin{array}{c}\text { Control (NPK) + lime at } 2.5 \mathrm{Hy} \\
2007 \text { year }\end{array}$ & 1.4 & $\frac{0.22}{15.7}$ & $\frac{0.16}{11.4}$ & $\frac{0.20}{14.0}$ & $\frac{0.58}{41.1}$ & $\frac{0.29}{20.7}$ \\
\hline $\begin{array}{c}\text { Control (NPK) + lime at } 2.5 \mathrm{Hy} \\
2008 \text { year }\end{array}$ & 1.4 & $\frac{0.16}{11.4}$ & $\frac{0.16}{11.4}$ & $\frac{0.27}{19.3}$ & $\frac{0.59}{42.1}$ & $\frac{0.35}{25.1}$ \\
\hline $\begin{array}{c}\text { Control (NPK) + lime at } 2.5 \mathrm{Hy} \\
2009 \text { year }\end{array}$ & 1.4 & $\frac{0.22}{15.7}$ & $\frac{0.22}{15.7}$ & $\frac{0.14}{10.0}$ & $\frac{0.58}{41.4}$ & $\frac{0.29}{20.5}$ \\
\hline $\begin{array}{l}\text { Control (NPK) + lime at } 2.5 \mathrm{Hy} \\
2010 \text { year }\end{array}$ & 1.4 & $\frac{0.19}{13.6}$ & $\frac{0.18}{12.8}$ & $\underline{0.15}$ & $\frac{0.52}{37.1}$ & $\frac{0.37}{26.7}$ \\
\hline $\mathrm{LSD}_{05}$ & - & 2.45 & 3.54 & 1.65 & 4.34 & 2.45 \\
\hline
\end{tabular}

Note. Hy - hydrolytic acidity of lime, above line is percent of soil; below line is percent of total C; LSD is given for content of total C.

$$
\begin{array}{cr}
\text { for HA1: } \mathrm{y}_{5}(t)=0.452-0.2419 t+0.07143 t^{2}- \\
0.0067 t^{3}, \quad \text { model } 5 \\
\text { for HA2: } \mathrm{y}_{6}(t)=0.116-0.0269 t+0.02893 t^{2}- \\
0.0042 t^{3}, \quad \text { model } 6 \\
\text { for HA3: } \mathrm{y}_{7}(t)=-0.076+0.31976 t-0.1011 t^{2}+ \\
0.00917 t^{3}, \quad \text { model } 7
\end{array}
$$$$
0.0025 t^{3}
$$$$
\text { for NR: } \mathrm{y}_{8}(t)=0.53-0.1764 \mathrm{t}+0.04107 t^{2}-
$$

where $t$ is time, years.

The number of observations (five) for four parameters is not suitable to check the statistical significance by Fisher criteria. The coefficient of determination for HA1 is $R^{2}=0.75$, for $\mathrm{HA} 2-R^{2}=0.835$, for $\mathrm{HA} 3-R^{2}=0.60$ and for $\mathrm{NR}-R^{2}=0.55$. Figures 5 to 8 present these models.

We have developed the accurate models, the values of which, at the point $t$ from the table coincide with the experimental data HA1, HA2, HA3 and humin. Using the linear regression, we get:

$$
\begin{array}{rr}
\text { HA1: } \mathrm{y}_{9}(t)=-0.16+0.91167 t- & 0.6308 t^{2}+ \\
\text { model } 9, \\
0.163337 t^{3}-0.0142 t^{4}, & \\
\text { HA2: } \mathrm{y}_{10}(t)=-0.37+0.88917 t- & 0.5288 t^{2}+ \\
0.130837 t^{3}-0.0113 t^{4}, & \text { model } 10,
\end{array}
$$

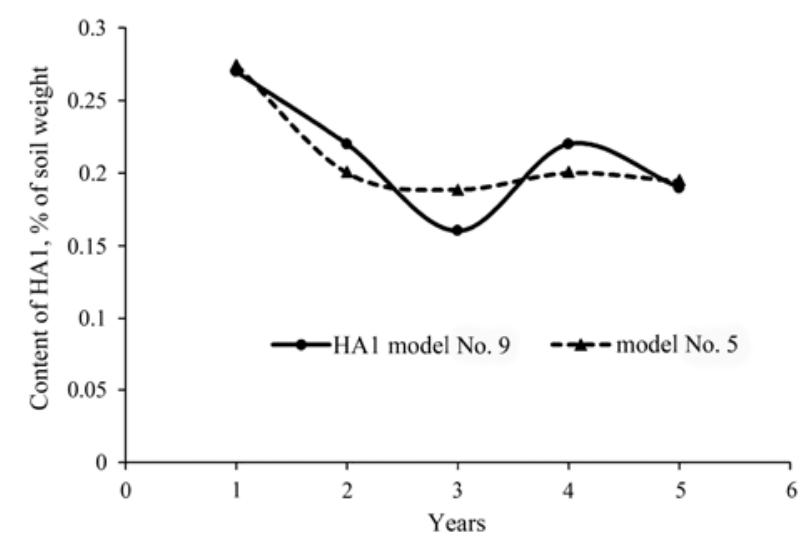

Figure 5. Changes in the content of HA1 during dissolution of lime

$$
\begin{gathered}
\text { HA3: } \mathrm{y}_{11}(t)=0.95-1.6142 t+\begin{array}{c}
1.07625 t^{2}- \\
\text { model } 11,
\end{array} \\
0.2758 t^{3}+0.02375 t^{4}, \\
\text { NR: } \mathrm{y}_{12}(t)=1.525-2.0425 t+\begin{array}{c}
1.17708 t^{2}- \\
\text { model } 12,
\end{array} \\
0.27758 t^{3}+0.02292 t^{4}, \\
\text { where } t \text { is time, years. } \\
\text { The number of observations coincides with }
\end{gathered}
$$
the number of the model parameters (models 9-12). Coefficient of determination for the models is $R^{2}=1$ (Figs. 5-8).

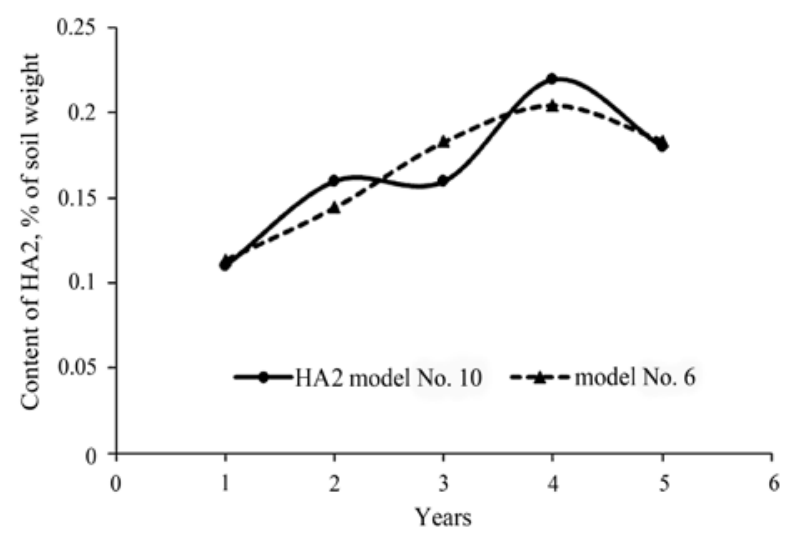

Figure 6. Changes in the content of HA2 during dissolution of lime

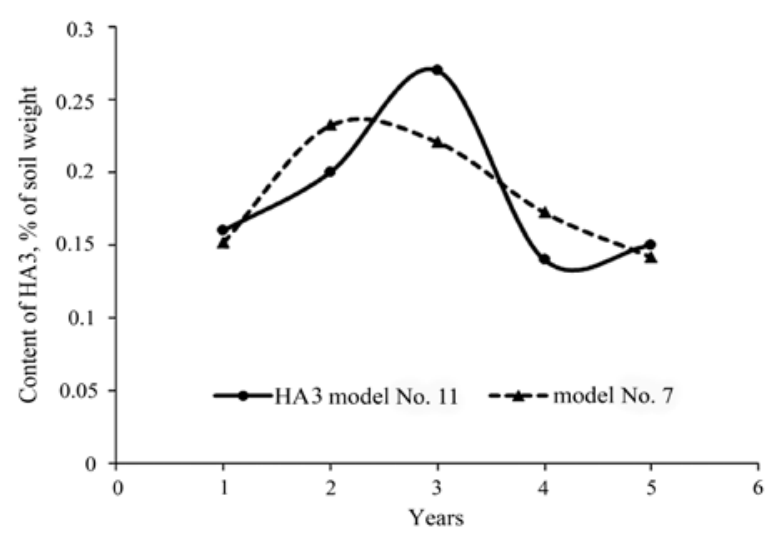

Figure 7. Changes in the content of HA3 during during dissolution of lime 


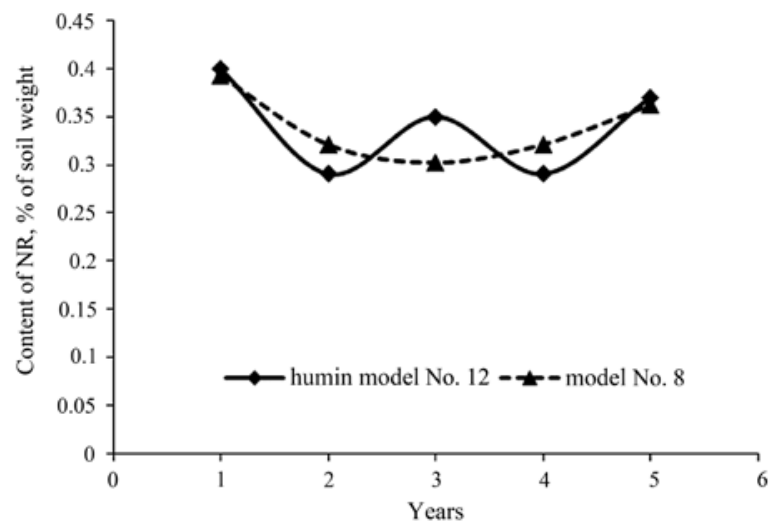

Figure 8. Changes in the content of humin (NR) dissolution of lime

\section{Conclusion}

Under controlled conditions of pot experiment of liming of Umbric Albeluvisol Abruptic the humus C was not changed at 0.1-1.6 hydrolytic acidity (Hy) of lime. When using a lime dose equal to $2.5 \mathrm{Hy}$, a tendency of accelerated mineralization of humus was observed.

Liming boosted hydrolysability of humus. With increasing doses of lime a gradual decrease of humin (NR) and increase in the amount of humic acids (HA) was observed.

Correlation coefficient between humin and $\Sigma$ HA was $r=-0.49$. Negative correlations were observed between the amounts of humin and HA1 $(r=-0.37)$ and humin and HA2 $(r=-0.75)$. A statistically significant relationship between the changes in the content of HA1 and HA2, because of the rearrangement in the humus composition was not revealed. Based on the analysis of literature data and our research findings we suggest that the source of replenishment of the proportion of humic acids can be organic substances of humin. The use of the tested increased doses of lime might have contributed to strengthening the fixation of humus by soil mineral part. The increase of HA3 content (strongly associated with clay minerals and resistant forms of sesquioxides) was observed in the lime dose equal to $0.9 \mathrm{Hy}$ and higher. Content of HA3 in the treatment applied with 2.5 hydrolityc acidity lime exceeded content of HA2.

Empirical models of transformation of humic acid and humin with increasing doses of ameliorant and during its dissolution were developed. The data of the optical density of humic acids was presented to support the obtained data.

Received 18072016

Accepted 20012017

\section{References}

Alexandrova L. N. 1980. Soil organic matter and processes of its transformation. Leningrad, Russia, 287 p. (in Russian)

Bakina L. G., Drichko V. F. 2011. Interaction of different humic acid fractions from clayey sod-podzolic soils with calcium. Eurasian Soil Science, 44 (12): 1333-1342 https://doi.org/10.1134/S1064229311080023
Bakina L. G., Chugunova M. V., Zaitseva T. B., Nebolsina Z. P. 2014. The effect of liming on the complex of soil microorganisms and the humus status of a sod-podzolic soil in a long-term experiment. Eurasian Soil Science, 47 (2): $110-118$ https://doi.org/10.1134/S1064229314020021

Bure V. M., Parilina E. M. 2013. Probability theory and mathematical statistics. St. Petersburg, Russia, 416 p.

Cherkinskiy A. Ye. 1992. Radiocarbon method in soil humic acids transformation studies. Pochvovedenie, 1: 162-166 (in Russian)

Clapp C. E., Hayes M. H., Simpson A. J., Kingery W. L. 2005. Chemistry of soil organic matter. Chemical processes in soils. SSSA Book Series, No. 8

Jokubauskaite I., Amaleviciute K., Lepane V., Slepetiene A., Slepetys J., Liaudanskiene I., Karcauskiene D., Booth C. A. 2015. High-performance liquid chromatography (HPLC)size exclusion chromatography (SEC) for qualitative detection of humic substances and dissolved organic matter in mineral soils and peats in Lithuania. International Journal of Environmental Analytical Chemistry, 95 (6): 508-519 https://doi.org/10.1080/03067319.2015.1048435

Jokubauskaite I., Karčauskienė D., Slepetiene A., Repsiene R., Amaleviciute K. 2016. Effect of different fertilization modes on soil organic carbon sequestration in acid soils. Acta Agriculturae Scandinavica, Section B: Soil and Plant Science, 66 (8): 647-652 https://doi.org/10.1080/09064710.2016.1181200

Kögel-Knabner I., Chenu C., Kandeler E., Piccolo A. 2006. Biological and physicochemical processes and control of soil organic matter stabilization and turnover. European Journal of Soil Science, 57 (4): 425 https://doi.org/10.1111/j.1365-2389.2006.00841.x

Kononova M. M. 1963. Organic matter of soil. Moscow, Russia, 314 p. (in Russian)

Liaudanskienè I., Šlepetienè A., Velykis A. 2011. Changes in soil humified carbon content as influenced by tillage and crop rotation. Zemdirbyste-Agriculture, 98 (3): 227-234

Litvinovich A. V., Pavlova O. Yu. 2007. Changes in the humus status of a layland sandy gleyic sod-podzolic soil. Eurasian Soil Science, 40 (11): 1181-1186 https://doi.org/10.1134/S1064229307110051

Litvinovich A. V., Pavlova O. Yu. 2010. Transformation of the humus composition in light-textured sod-podzolic soils as affected by increasing lime doses and in the postagrogenic period. Eurasian Soil Science, 43 (11): 1263-1270 https://doi.org/10.1134/S1064229310110098

Litvinovich A. V., Pavlova O. Yu. 2014. Transformation of humus of sod-podzolic loamy sand soil under liming by ameliorant of calcareous nature. Agrochemistry, 3: 22-27

Litvinovich A. V., Pavlova O. Yu., Maslova A. I., Lavrishchev A. V., Kolodka V. P. 2000. Humus composition in the loamy sand sod-podzolic soil limed with waste lime. Eurasian Soil Science, 33 (2): 144-147

Lopez-Sangil L., Rovira P. 2013. Sequential chemical extractions of the mineral-associated soil organic matter: an integrated approach for the fractionation of organo-mineral complexes. Soil Biology and Biochemistry, 62: 57-67 https://doi.org/10.1016/j.soilbio.2013.03.004

Orlova N. E. 1981. Comparative study of the composition and properties of humus of brown forest and sod-podzolic soils. $\mathrm{PhD}$ thesis. Leningrad, Russia, 24 p. (in Russian)

Plotnikova T. A., Orlova N. E. 1984. Modified schemes of Ponomareva-Plotnikova to determine the composition, nature and properties of soil humus. Pochvovedenie, 8: 120-130 (in Russian) 
Ponomareva V. V., Plotnikova T. A. 1968. Methodology and some results of fractionation of humus of Chernozems. Pochvovedenie, 11: 104-117 (in Russian)

Pridvorev N. I., Dedov A. V., Verzilin V. V., Korolev N. N 2006. Nonhydrolyzable residue in humus of chernozems. Eurasian Soil Science, 39 (4): 403-409 https://doi.org/10.1134/S1064229306040077

Schmidt M. W. I., Torn M. S., Abiven S., Dittmar T., Guggenberger G., Janssens I. A., Kleber M., KögelKnabner I., Lehmann J., Manning D. A. C., Nannipieri P., Rasse D. P., Weiner S., Trumbore S. E. 2011. Persistence of soil organic matter as an ecosystem property. Nature, 478 (7367): 49-56 https://doi.org/10.1038/nature10386

Takahashi T., Ikeda Yu., Fujita K., Nanzyo M. 2006. Effect of liming on organically complexed aluminum of nonallophanic Andosols from northeastern Japan. Geoderma, 130 (1-2): 26-34

https://doi.org/10.1016/j.geoderma.2005.01.006
Tyurin I. V. 1937. Soil organic matter and its role in soil formation and fertility. Studies on soil humus. Moscow, Russia, 287 p. (in Russian)

WRB 2014. World reference base for soil resources 2014 . International soil classification system for naming soils and creating legends for soil maps. World Soil Resources Reports No. 106. FAO, Rome

Zavyalova N. E. 2010. Organic matter of sod-podzolic hard loamy soils in different land use systems. Impact of prolonged use of fertilizers on soil organic matter. Moscow, Russia, p. 190-230

Unified State Register of Soil Resources of Russia, version 1.0. 2014. V. V. Dokuchaev Soil Science Institute, Moscow, Russia (in Russian)

ISSN 1392-3196 / e-ISSN 2335-8947

Zemdirbyste-Agriculture, vol. 104, No. 2 (2017), p. 115-122

DOI 10.13080/z-a.2017.104.015

\title{
Huminių rūgščių ir humino transformacijų Umbric Albeluvisol Abruptic empirinis modelis, priklausomai nuo dirvožemio kalkinimo
}

\author{
A. Litvinovich ${ }^{1}$, O. Pavlova ${ }^{1}$, A. Lavrishchev², V. Bure ${ }^{1,3}$, E. Saljnikov ${ }^{4}$ \\ ${ }^{1}$ Rusijos agrofizinių tyrimų institutas \\ ${ }^{2}$ Sankt Peterburgo valstybinis žemès ūkio universitetas, Rusija \\ ${ }^{3}$ Sankt Peterburgo valstybinis universitetas, Rusija \\ ${ }^{4}$ Serbijos dirvožemio mokslo institutas
}

\section{Santrauka}

Tirta anglies suminio kiekio - huminių rūgščių (HA) anglies ir nehidrolizuojamos liekanos humino - pokyčiai Umbric Albeluvisol Abruptic (umABap), dirvožemị pakalkinus ịvairiomis dozèmis $(0,1-2,5$ hidrolizinio rūgštumo (Hy) mekv. $100 \mathrm{~g}$ dirvožemio) kalkių vegetaciniuose induose kontroliuojamomis sąlygomis. Humuso kiekio mažèjimo dirvožemyje tendencija nustatyta tik pakalkinus didžiausia doze $(2,5 \mathrm{Hy})$ kalkių. Priklausomai nuo kalkių dozès, nustatytas palaipsnis humino dalies mažèjimas ir huminių rūgščių dalies didejjimas. Koreliacijos koeficientas tarp humino ir $\Sigma$ HA buvo $r=-0,49$. Nustatyta vidutiniškai neigiama koreliacija tarp humino kiekio ir HA1 laisvos ir sujungtos su pusantriniais oksidais: $r=-0,37$; tarp humino ir HA2, sujungtos su kalciu: $r=-0,75$. Huminių rūgščių 1 ir 2 frakcijos koreliavo neesmingai. Humuso kiekio padidejimas HA3 frakcijoje, kuri yra stipriai sujungusi su molio mineralais ir stabiliomis pusantrinių oksidu formomis, nustatytas tik pakalkinus 0,9 Hy. Pakalkinus 2,5 Hy, humuso kiekis viršijo HA2 kiekį. Irodyta tyrimo hipotezè, kad huminių rūgščių dalies papildymo šaltinis gali būti humino organinès medžiagos. Priklausomai nuo didejjančių kalkių dozių ir jų tirpimo, sukurti empiriniai huminių rūgščių ir humino transformacijos modeliai, pateikti huminių rūgščių optiniai tankiai.

Reikšminiai žodžiai: frakcionavimas, hidrolizinis rūgštumas, huminas, huminių rūgščių frakcijos, kalkinimas. 